\title{
唇顎口蓋裂者の咬合の安定性についての筋電図学的研究
}

\author{
尹 泳薰, 山本隆昭, 今井 徹, 中村進治 \\ 北海道大学歯学部歯科矯正学講座 (主任: 中村進治) \\ 〔受付：平成 7 年 10 月 2 日]
}

\section{Electromyographic study on occlusal stability in cleft lip and palate patients}

\author{
Young Hoon Yoon, Takaaki Yamamoto, Tohru Imai, Shinji Nakamura \\ Department of Orthodontics, School of Dentistry, Hokkaido University \\ (Director: Shinji Nakamura) \\ [Recieved: October 2, 1995.]
}

Key words: Cleft lip and palate, Occlusal stability index, Masseter muscle activity, 9 channel EMG analyzing system, Asymmetry index

\begin{abstract}
The purpose of this study was to investigate the relationship between the occlusal stability and the masseter muscle activity in cleft lip and palate patients. Eighteen subjects were selected and divided into 6 groups; children and adults with normal occlusion as normal child group and normal adult group, cleft lip and/or palate child patients and adult patients without constricted upper arch at initial examination as child non-constricted arch group and adult non-constricted arch group, cleft lip and/or palate child patients and adult patients with constricted upper arch at initial examination as child constricted arch group and improved constricted arch group. The occlusal stability of posterior teeth was evaluated by calculating the occlusal stability index, and the masseter muscle activity was measured with the 9 channel EMG analyzing system in the subjects. And also, their symmetries were estimated by the asymmetry index.
\end{abstract}

The results were as follows:

1) The occlusal stability index and the masseter muscle activity in the child constricted arch group were lower than those of normal child group and child non-constricted arch group. Also, the child constricted arch group showed higher value of asymmetry index than other groups.

2) A strong positive correlation between the occlusal stability index and the mi ...r muscle activity were admitted in the child groups $(\mathrm{r}=0.96)$.

3) The masseter muscle activity of the child constricted arch group was increased and the asymmetry index was reduced after wearing an occlusal splint for 10 days.

4) Comparing the child subjects with adult subjects, the occlusal stability index and the masseter muscle activity of the adults were higher than those of children.

Especially, the occlusal stability index and the masseter muscle activity were eminently ameliorated in improved constricted arch group. We think this result is due to the improvement of the stability of posterior teeth after orthodontic treatment.

連絡先： $\bar{\top} 060$ 札幌市北区北13条西 7 丁目 
抄 録 上顎骨や上顎歯列弓に様々な形態異常が認められる唇顎口蓋裂患者の咬合状態が，咬筋筋活動量 に与える影響を調べることを目的に研究を行った。被験者に小児掞よび成人の正常咬合者と唇顎口蓋裂者 の18名を用い, さらに唇顎口蓋裂者を上顎歯列弓に狭窄のある群(狭窄群) とない群 (非狭宱群)に分けた. これら被験者に対し，上下顎臼歯部の咬合接触状態を数值で表現するため新たに考案した咬合安定指数と, 9 チャンネル筋電図分析システムによる咬筋筋活動量, およびそれらの非対称性指数を計測した.

研究結果は以下のとおりであった。

1. 小览被験者の咬合安定指数と咬筋筋活動量では，正常群と非狭窄群に比べ狭窄群が著しく低い值を示 し，それらの左右側の対称性も低かった.

2. 咬合安定指数と咬筋筋活動量とには強い正相関 $(\mathrm{r}=0.96)$ が認められた.

3．小児唇顎口蓋裂者の狭窄群に咬合接触状態を安定させるためスプリントを10日間装着させた結果，咬 筋筋活動量は増加し, 左右咬筋の非対称性も著明に改善した.

4. 小児被験者と成人被験者との咬合安定指数と咬筋筋活動量を比較した結果，いずれの群でも成人の方 が高い值を示していた．特に，狭窄群は他の 2 群に比べて著しい増加を示しており，矯正治療による 咬合の安定性の改善が認められた。

\section{I. 緒 言}

唇顎口蓋裂に見られる裂隙部の骨実質欠損や口蓋形成 手術後の瘏痕形成などは，上顎骨の劣成長や上顎歯列弓 の狭窄，歯の萌出位置異常などを引き起こす。このよう な口腔の形態異常は上下顎の咬合状態に影響を及ぼし, 咀嚼機能にも異常を生じさせていることが考えられる.

今までの唇顎口蓋裂者における筋電図学的な研究で は，咀嚼筋筋活動量に破裂側と非破裂側で差が認められ ないが，対合接触歯数が多いほど咀嚼リズムが安定して いること”，咀嚼筋筋活動において破裂側と非破裂側と の間にピーク周波数の有意差は認められないがサイレン トピリオドの延長が認められること²)，などが報告され ている。 また，咀嚼能率と咬合接触状態との関連性を指 摘している報告もある゙!。しかし，唇顎口蓋裂者の咬合 接触状態を数值的に表現し，それと咀嚼筋の筋活動性を 直接関連づけた研究は極めて少ない。

そこで，本研究では唇顎口蓋裂者の咬合状態，特に臼 歯部の咬合安定性が咬筋筋活動量に与える影響を調べる ことを目的で，小児および成人の正常咬合者と唇顎口蓋 裂者を対象に，両側の曰歯部の咬合状態と咬筋筋活動量 とを計測し検討を加えた。

\section{II. 研究方法}

\section{1. 被験者}

小児と成人の正常咬合者および唇顎口蓋裂者を被験者 とした，小児被験者は，矯正治療経験の無い正常咬合を
有する小览正常群 3 名, および本学歯学部附属病院矯正 科に来院した動的矯正治療開始前の唇顎口蓋裂者 6 名の 9 名である. 成人被験者は, 同じく矯正治療経験の無い 正常咬合を有する成人正常群 3 名と, 矯正治療を終了し た成人唇顎口蓋裂者 6 名の 9 名である.

次に，小児と成人の唇顎口蓋裂者を上顎歯列弓の狭窄 の有無によってそれぞれ 3 名づつの 2 群に分けた．図 1 に示すように, 初診時の上下顎歯列模型を用いて本教室 で考案した評価方法”により角度 $\alpha, \beta$ を算出し，いず れかが70度以下であったものを小巟狭窄群または成人元 狭窄群，両方とも70度以上であったものを小児または成 人非狭窄群とした(表1).

矯正を行った成人の動的矯正治療期間は成人元狭窄群 が平均 6 年 11 力, 成人非狭窄群では平均 4 年 3 か月で あった。

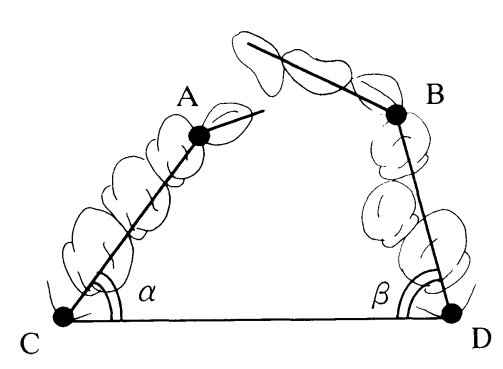

$\mathrm{A}:$ 患側上顎乳犬歯遠 心歯間乳頭の頂点 B:健側上顎乳犬㐘遠 心歯間乳頭の頂点 C:患側上顎結節最後 縁点

$\mathrm{D}$ :健側上顎結節最後 縁点

$\alpha$ :患側上顎側方歯槽 部傾斜度 $(\angle \mathrm{ACD})$ $3:$ 健側上顎側方歯槽 部傾斜度 $(\angle \mathrm{BDC})$

図 1 上顎歯列弓の狭窄の評価方法

Fig. 1 The evaluation method of maxillary arch costriction 
表 1 被験者

Table 1 Subjects

\begin{tabular}{|c|c|c|c|c|c|c|}
\hline \multirow{2}{*}{ 群 } & \multirow{2}{*}{ 被験者 } & \multirow{2}{*}{ 性別 } & \multirow{2}{*}{ 年 齢 } & \multirow{2}{*}{ 裂 } & \multicolumn{2}{|c|}{ 上顎側方歯槽部傾斜度 } \\
\hline & & & & & 右 側 & 左 側 \\
\hline \multirow{3}{*}{ 小児正常群 } & 1 & 男 & 6 歳 7 カ月 & & $73^{\circ}$ & $73^{\circ}$ \\
\hline & 2 & 女 & 11 歳 5 力月 & & $77^{\circ}$ & $75^{\circ}$ \\
\hline & 3 & 男 & 9 歳 0 力月 & & $75^{\circ}$ & $75^{\circ}$ \\
\hline \multirow{3}{*}{ 成人正常群 } & 1 & 男 & 25 歳 5 力月 & & & \\
\hline & 2 & 女 & 19歳 1 力月 & & & \\
\hline & 3 & 男 & 29歳 4 力月 & & & \\
\hline \multirow{3}{*}{ 小児非狭窄群 } & 1 & 女 & 8 歳11カ月 & 右側口唇裂 & $76^{\circ}$ & $74^{\circ}$ \\
\hline & 2 & 女 & 11歳 1 力月 & 右側唇顎口蓋裂 & $73^{\circ}$ & $74^{\circ}$ \\
\hline & 3 & 女 & 8 歳 3 力月 & 左側口唇裂 & $73^{\circ}$ & $74^{\circ}$ \\
\hline \multirow{4}{*}{ 成人非狭窄群 } & 1 & 男 & 16歳11力月 & 左側唇顎口蓋裂 & $76^{\circ}\left(74^{\circ}\right)$ & $76^{\circ}\left(76^{\circ}\right)$ \\
\hline & 2 & 男 & 16歳 3 力月 & 左側唇顎口蓋裂 & $78^{\circ}\left(76^{\circ}\right)$ & $78^{\circ}\left(74^{\circ}\right)$ \\
\hline & 3 & 男 & 18歳 0 カ月 & 両側性口唇裂 & $78^{\circ}\left(75^{\circ}\right)$ & $78^{\circ}\left(74^{\circ}\right)$ \\
\hline & & & & & 狭窄側 & 非狭窄側 \\
\hline \multirow{3}{*}{ 小児狭窄群 } & 1 & 男 & 9 歳 0 力月 & 左側唇顎口蓋裂 & $67^{\circ}$ & $75^{\circ}$ \\
\hline & 2 & 女 & 8 歳 3 力月 & 左側唇顎口蓋裂 & $67^{\circ}$ & $75^{\circ}$ \\
\hline & 3 & 男 & 9 歳 6 力月 & 口蓋裂 & $67^{\circ}$ & $74^{\circ}$ \\
\hline \multirow{3}{*}{ 成人元狭窄群 } & 1 & 男 & 19歳 9 力月 & 左側唇顎口蓋裂 & $72^{\circ}\left(62^{\circ}\right)$ & $75^{\circ}\left(75^{\circ}\right)$ \\
\hline & 2 & 女 & 17 歳 8 力月 & 左側唇顎口蓋裂 & $76^{\circ}\left(65^{\circ}\right)$ & $77^{\circ}\left(70^{\circ}\right)$ \\
\hline & 3 & 男 & 19歳11力月 & 右側唇顎口蓋裂 & $71^{\circ}\left(48^{\circ}\right)$ & $78^{\circ}\left(73^{\circ}\right)$ \\
\hline
\end{tabular}

\section{2. 上下顎臼歯部の咬合安定性の評価}

上下顎臼歯部における咬合接触の安定性を評価するた め, 新たな指数として咬合安定指数 (Occlusal stability index：以下OSI）を考案した。この咬合安定指数は上下 顎臼歯部の咬合接触状態, 㚘舌舌的な被蓋関係および咬合 接触している歯数の 3 つの観点から咬合の安定性を表現 しようとしたものである. 正常者, 初診時の小児唇顎口 蓋裂者と治療終了時の成人唇顎口蓋裂者の上下顎㐘列模 型を用いて, 以下に示す数式によってOSI值を算出し た。

$$
\begin{gathered}
\text { OSI }=\sum_{\mathrm{n}=1}^{\mathrm{c}}\left(\mathrm{an}_{\mathrm{n}}+\mathrm{b}_{\mathrm{n}}\right) / \mathrm{c}+\mathrm{d} \\
1 \leqq \mathrm{n} \leqq \mathrm{c}
\end{gathered}
$$

$a_{n}$ : 下顎臼歯 1 本づつの咬合接触指数

対合歯と 1 点で咬合する場合 +1

対合歯と複数点または面で咬合する場合 +2

機能咬頭が対合歯の窩で咬合する場合+3

ここで口腔内で採得したシリコーン系咬合採得材

の穿孔部分が直径 $1 \mathrm{~mm}$ 以下のものを点, 直径 1 $\mathrm{mm}$ より大きいものを面と判断した。

$\mathrm{b}_{\mathrm{n}}$ : 下顎臼歯1本づつの㚘舌的被蓋関係の指数

正常被蓋をもつ場合 +1

正常被蓋をもっていない場合 0 c：咬合接触状態を評価した下顎臼歯の総歯数

$\mathrm{d}$ ：下顎臼歯の総歯数 c から 1 を引いた值

このOSIは片側小臼歯から大正歯部までの咬合状態を 高道 ${ }^{5)}$ の考案した咬合接触指数に日歯部の㚘舌的被蓋 関係の指数と咬合接触歯数とを加え数值的に表わしたも のである．㚘頁的な被蓋関係を表わす指数を加えた理由 としては，臼歯部交叉咬合の場合には側方運動時の咬頭 干渉などにより咀嚼筋活動に悪影響を及ぼすことや， 歯の歯軸に垂直的に咬合力が加わらず，十分な咬合力を 発揮できなくなる，などが考えられたためである。しか し，咬頭嵌合位における最大咬合力の大きさに影響を与 える因子としては，煩舌的被蓋関係よりもむしろ咬合接 触状態の方がより重要と考え， $b_{n}$ より $a_{n}$ がより大きな 值となるように設宗した。すなわち，咬合接触指数の最 高は 3 点で頬舌以被蓋関係の指数の最高は 1 点である. なおOSIの最高值は小児で 6, 成人で 7 である.

\section{3. 咬筋の筋電図記録方法と時期}

筋電図計測は本教室で開発した 9 チャンネル筋電図分 析システムㅎำ用いて行なった。図 2 は被験者の咬筋相 当部に電極板を貼付した模式図である。電極板は軟性熱 硬化性シリコーン樹脂を用いて作製し，直径 $4 \mathrm{~mm}$ の銀塩化銀表面電極を縦 $15 \mathrm{~mm}$ 間隔で 4 個, 横 $15 \mathrm{~mm}$ 間隔で 3 個の合計12個を格子状に配列し, 縦方向に双極導出し, 片側 9 チャンネルの合計18チャンネルで両側咬筋を同時 


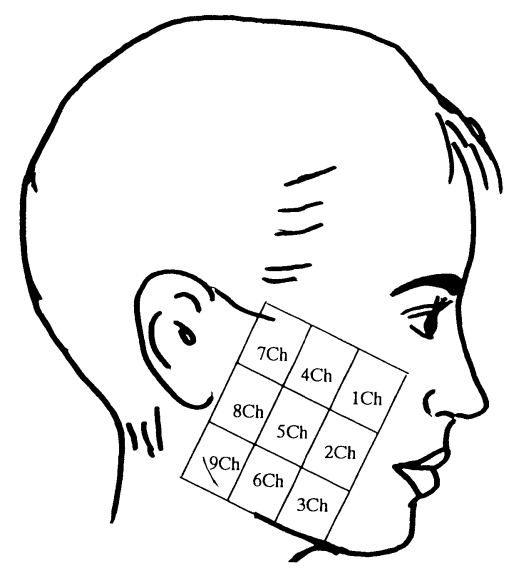

図29チャンネル筋電図分析システムの電 極板の貼付位置

Fig. 2 Diagram of placement of electrods in the 9 channel EMG analyzing system

記録した．電極板の貼付位置は触診により確認した咬筋 前縁を電極板前縁に，また下顎骨下縁を電極板下縁に一 致させ，咬筋走行と平行に貼付し，不関電極を前額部に 設定した。

筋電図記録は全てシールドルーム内で行ない，被験者 のフランクフルト平面が床面に対しほほ平行な状態にな るように木製の椅子に座らせた。被験者に30回／分の速 度で最大咬み締めを 6 回行わせ， 1 回の咬み締め持続時 間を 1 秒として，その時の咬筋筋活動を記録した。

分析の対象とした筋電図波形は，6回の最大咬み締め のうち最初と最後を除く合計 4 回の波形を用い筋活動量 を算出した。まず，1 回の咬み締め毎の各チャンネルで の平均振幅值 $(\mu \mathrm{V})$ を算出し, この平均振幅值を用いて 左右側それぞれ 9 チャンネルの総和を求めた。ささらに 4 回の咬み締めの相加平均を算出し，これを各被験者にお ける左側および右側の咬筋全体の平均筋活動量 $(\mu \mathrm{V})$ と した(罒3)。

また，同一被験者における上下顎臼歯部の咬合状態の 変化が咬筋筋活動に与える影響を調べるため, OSI值が 最も低かった小児狭窄群を対象に，常温重合レジン製の スプリントを上顎に装着し，咬合接触状態を安定させた 後に再度筋電図記録を行なった。スプリントは上顎歯列 の左右側のそれぞれ犬歯から甶歯までを覆う形とし， OSI值が正常咬合者と同じ値をとるまで下䪽臼歯と咬合 接触するように調整し，10日間装着させた。なお，スプ リント装着による咬合高径の変化が筋活動に与える影響 を少なくするため，スプリントによる咬合挙上量は前歯 部で $3 \mathrm{~mm}$ 以内としたて..1.

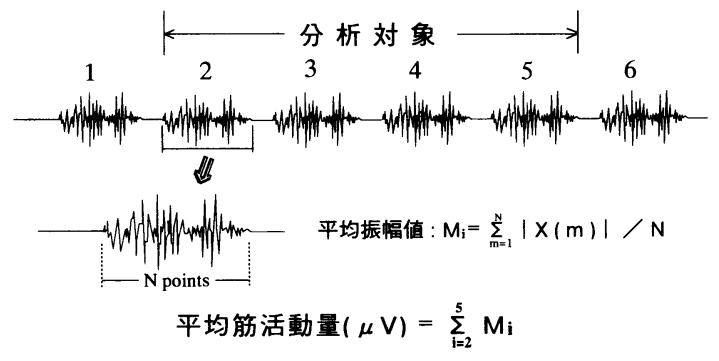

図 3 筋電困波形の分析方法

Fig. 3 The analyzing method of EMG signals of masseter muscles

\section{4. 左右側の対称性の評価}

両側の咬筋筋活動量および上下顎臼歯部の咬合安定性 の左右差を，Naeijeらによって考案された非対称性指数 ${ }^{9}$ (Asymmetry Index：以下AI)を用いて評価した。AI值は 下記の数式で計算される值で, この值が大きいほど, 左 右の非対称性が強いことを表わす。

$\mathrm{AI}=\mid$ Right - Left $|/|$ Right + Left $\mid \times 100(\%)$

\section{III. 結 果}

\section{1. 小児群での研究結果}

表 2 に小児の正常群と唇顎口蓋裂者 (狭窄群, 非狭窄 群) の咬合安定指数 (OSI) と咬筋筋活動量, およびそれ らの非対称性指数 $(\mathrm{AI})$ の結果をまとめた.

1 ) 咬合安定指数

OSI值の算出結果では，正常群で左右側とも5.45であ り, 非狭窄群では左側が 4.72 , 右側が 5.00 , 両側の平均 が4.86であり，両群間での差はほとんどなかった。また， OSIのAI值の算出結果では, 正常群が $0 \%$, 非狭窄群が $3.07 \%$ ともに低い值を示していた。これに対し，狭窄 群のOSI值では狭窄が認められた側が 2.67 , 狭窄が認め られなかった側が1.83で両側の平均が 2.25 と, 正常群や 非狭窄群に比べて明らかに低い值を示していた。また， $\mathrm{AI}$ 值は $20.81 \%$ と他の 2 群に比べ著しく高い值を示して いた。

したがって，矯正治療を行っていない小児唇顎口蓋裂 者の狭窄群は正常群や非狭窄群に比べて，その上下顎臼 歯部咬合は不安定であり, しかも左右側の臼歯部咬合状 態の対称性も非常に損なわれていることが認められた。

2 ) 咬筋筋活動量

咬筋の平均筋活動量は正常群で左側が $156.8 \mu \mathrm{V}$, 右側

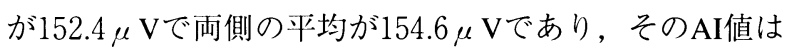
1.78\%であった。また，非狭窄群では左側が $135.3 \mu \mathrm{V}$, 
表 2 小児被験者での計測結果

Table 2 Experimental results in child subjects

\begin{tabular}{|c|c|c|c|c|c|c|c|c|c|}
\hline \multirow[b]{2}{*}{ 群 } & \multirow[b]{2}{*}{ 被験者 } & \multicolumn{4}{|c|}{ 咬合安定指数（OSI） } & \multicolumn{4}{|c|}{ 咬筋筋活動量 $(\mu \mathrm{V})$} \\
\hline & & 右 側 & 左 側 & 平 均 & $\mathrm{AI}(\%)$ & 右 側 & 左 側 & 平 均 & $\mathrm{AI}(\%)$ \\
\hline \multirow{4}{*}{ 正常群 } & 1 & 5.67 & 5.67 & 5.67 & 0 & 145.6 & 154.6 & 150.1 & 3 \\
\hline & 2 & 5 & 5 & 5 & 0 & 152.6 & 151 & 151.8 & 0.53 \\
\hline & 3 & 5.67 & 5.67 & 5.67 & 0 & 159 & 164.9 & 162 & 1.82 \\
\hline & 平 均 & 5.45 & 5.45 & 5.45 & 0 & 152.4 & 156.8 & 154.6 & 1.78 \\
\hline \multirow{4}{*}{ 非狭窄群 } & 1 & 4.33 & 4 & 4.17 & 3.96 & 127.6 & 113 & 120.3 & 6.07 \\
\hline & 2 & 5 & 4.5 & 4.75 & 5.26 & 159.5 & 138.3 & 148.9 & 7.12 \\
\hline & 3 & 5.67 & 5.67 & 5.67 & 0 & 153.8 & 154.6 & 154.2 & 0.26 \\
\hline & 平 均 & 5 & 4.72 & 4.86 & 3.07 & 147 & 135.3 & 141.1 & 4.44 \\
\hline \multirow{5}{*}{ 狭窄群 } & & 狭窄側 & 非狭窄側 & & & 狭窄側 & 非狭窄側 & & \\
\hline & 1 & 3 & 2 & 2.5 & 20 & 60.7 & 40.8 & 50.8 & 19.61 \\
\hline & 2 & 2 & 1 & 1.5 & 33.33 & 81.6 & 27.9 & 54.8 & 49.04 \\
\hline & 3 & 3 & 2.5 & 2.75 & 9.09 & 81.8 & 51.5 & 66.7 & 22.73 \\
\hline & 平 均 & 2.67 & 1.83 & 2.25 & 20.81 & 74.7 & 40.1 & 57.4 & 30.54 \\
\hline
\end{tabular}

右側が $147.0 \mu \mathrm{V}$, 両側の平均が $141.1 \mu \mathrm{V}$ あ゙あり，そのAI

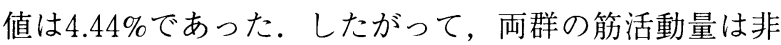
狭窄群の方が若干低い值を示していたが，その差はわず かであり，また両群ともにその筋活動量の左右差は小さ かった。

これに対し，狭窄群では狭窄が認められた側で $74.7 \mu$

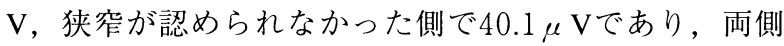
の平均が $57.4 \mu \mathrm{V}$ と, 正常群や非狭窄群に比べ明らかに 低い值を示していた。また，AI值は $30.54 \%$ と 2 群に比 ベて著しく高い值を示し，狭窄群の咬筋筋活動量の左右 差が大きいことが認められた。

3 ) 咬合安定指数と咬筋筋活動量との関係

上下顎臼歯部の咬合安定性と咬筋の筋活動量と関係を 調べるため, 両計測值の相関を求めた(図4). その結果, OSI值と咬筋筋活動量とは正比例関係であり，その相関 係数は $\mathrm{r}=0.96$ と強い正の相関を示していた。したがって， 臼歯部の咬合安定性と咬筋筋活動量とに強い関連性を認 めた。

\section{2.小児と成人との比較}

表 3 は成人被験者の咬合安定指数, 咬筋筋活動量とそ れらの非対称性指数の計測結果である。坚から成人へ の成長変化と矯正治療による咬合改善後の変化を評価す るため, 今回計測した正常群, 非狭窄群, 狭窄群 3 群で の小児と成人との横断的資料を用いて比較検討を行っ た。

小児と成人とのOSI值の比較では，3 群とも成人が小 児より高い值を示し, 小児・成人各群での増加率を求め

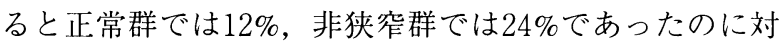
し，狭窄群が $139 \%$ と著しく増加していた。また，その

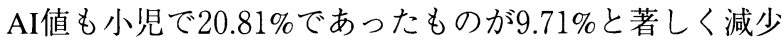
していた.

小児と成人の咬筋筋活動量の比較では，同じく 3 群と も成人が小児より高い值を示していた。増加率を 3 群間 で比較すると，正常群および非狭窄群の増加率43\%, $54 \%$ に比べ狭窄群が $246 \%$ の増加を示しており，AI值も

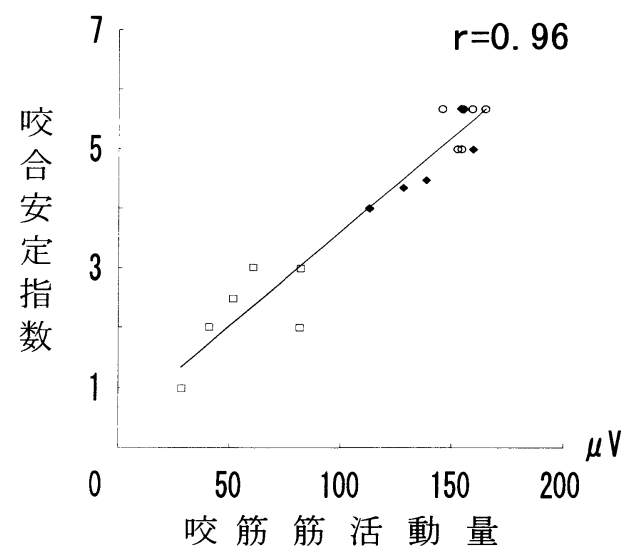

図 4 小览被験者における咬筋筋活動量と咬 合安定指数との相関図

$\bigcirc$ 小坚正常群

、小览非狭窄群 $\square$ 小览狭窄群

Fig. 4 Correation between the occlusal stability index and the masseter muscle activity in child subjects

Normal child group

Child non-constricted arch group

$\square$ Child constricted arch group 
表 3 成人被験者での計測結果

Table 3 Experimental results in adult subjects

\begin{tabular}{|c|c|c|c|c|c|c|c|c|c|}
\hline \multirow[b]{2}{*}{ 群 } & \multirow[b]{2}{*}{ 被験者 } & \multicolumn{4}{|c|}{ 咬合安定指数（OSI） } & \multicolumn{4}{|c|}{ 咬筋筋活動量 $(\mu \mathrm{V})$} \\
\hline & & 右 側 & 左 側 & 平 均 & $\mathrm{AI}(\%)$ & 右 側 & 左 側 & 平 均 & $\mathrm{AI}(\%)$ \\
\hline \multirow{4}{*}{ 正常群 } & 1 & 5.33 & 5.33 & 5.33 & 0 & 202.9 & 209.6 & 206.3 & 1.62 \\
\hline & 2 & 6.5 & 6 & 6.25 & 4 & 230.6 & 208.5 & 219.6 & 5.03 \\
\hline & 3 & 6.75 & 6.75 & 6.75 & 0 & 237.8 & 241.1 & 239.5 & 0.69 \\
\hline & 平 均 & 6.19 & 6.03 & 6.11 & 1.33 & 223.8 & 219.7 & 221.8 & 2.45 \\
\hline \multirow{4}{*}{ 非狭窄群 } & 1 & 5 & 5.67 & 5.34 & 6.28 & 190.4 & 213.4 & 201.9 & 5.7 \\
\hline & 2 & 6 & 6.5 & 6.25 & 4 & 209.8 & 239.8 & 224.8 & 6.67 \\
\hline & 3 & 6.25 & 6.75 & 6.5 & 3.85 & 210 & 240.5 & 225.3 & 6.77 \\
\hline & 平 均 & 5.75 & 6.31 & 6.03 & 4.71 & 203.4 & 231.2 & 217.3 & 6.38 \\
\hline \multirow{5}{*}{ 元狭窄群 } & & 元狭窄側 & 元非狭窄側 & & & 元狭窄側 & 元非狭窄側 & & \\
\hline & 1 & 6 & 5 & 5.5 & 9.09 & 221.7 & 168 & 194.9 & 13.78 \\
\hline & 2 & 5.7 & 4.5 & 5.1 & 11.76 & 217.1 & 174.6 & 195.9 & 10.85 \\
\hline & 3 & 6 & 5 & 5.5 & 9.09 & 243.3 & 166.7 & 205.1 & 18.7 \\
\hline & 平 均 & 5.9 & 4.83 & 5.37 & 9.71 & 227.4 & 169.8 & 198.6 & 14.44 \\
\hline
\end{tabular}

小児の $30.54 \% に$ 比べ成人では $14.44 \%$ と著しく減少して いた。

\section{3. 小児唇顎口蓋裂者のスプリント装着の効果}

臼歯部の咬合の安定性が最も低かった小児狭窄群にス プリントを10日間装着させ，咬合接触状態を正常者と同 等まで回復させた場合の咬筋筋活動量とそのAI值の変 化を図 5 と図 6 に示す。この結果, 全ての被験者で最大

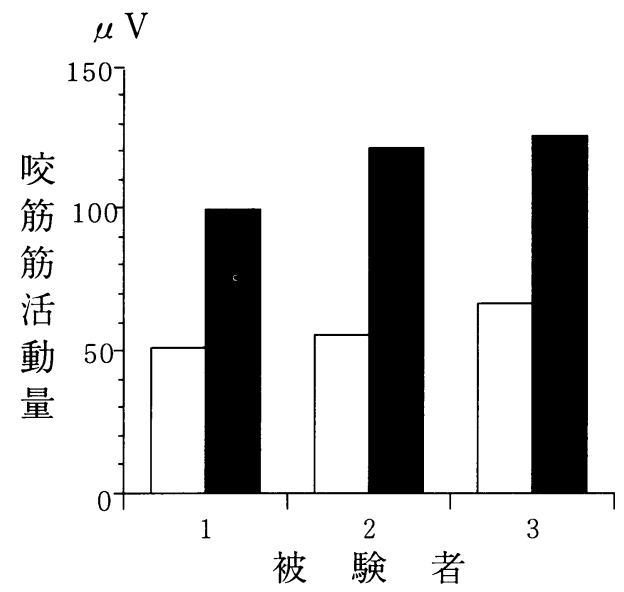

図 5 小児唇顎口蓋裂者の狭窄群における咬 筋筋活動量のスプリントによる効果

$\square$ スプリント装着前

ロスプリント装着後

Fig. 5 Effect of occlusal splint on the masseter muscle activity in child constricted arch group

$\square$ Before wearing splint

After wearing splint
咬み締め時の咬筋筋活動量は平均 $58 \mu \mathrm{V}$ 増加し, . 筋活動 量のAI值はスプリント装着前の平均 $30.54 \%$ から装着後 の $6.57 \%$ と減少しており，小児非狭窄群とほぼ同じ值 になっていった。

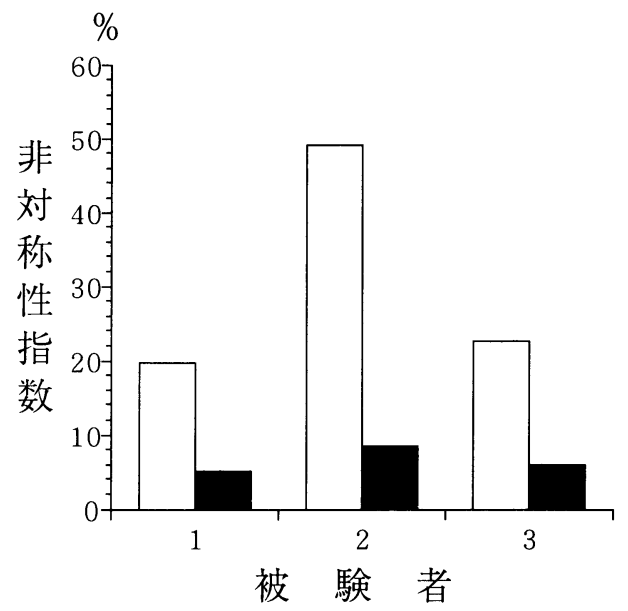

図 6 小児唇顎口蓋裂者の狭窄群における咬 筋筋活動量の非対称性のスプリントに よる効果
$\square$ スプリント装着前
ロ スプリント装着後

Fig. 6 Effect of occlusal splint on the AI of masseter muscle activity in child constricted arch group

$\square$ Before wearing splint

After wearing splint 


\section{IV. 考察}

\section{1. 実験方法ついて}

従来の唇顎口蓋裂者に関する筋電図学的研究は，ほと んどが片側性唇顎口蓋裂を対象として，破裂側と非破裂 側との比較や正常者との比較で評価を行なっていた。し かし，筋活動量や咬合力発現に深く関与している上顎歯 列弓狭窄の程度や臼歯部の咬合状態を十分に考慮してい ないため, 筋電図学的に有効な所見が見出されていない. そこで, 本研究では様々な裂型をもつ唇顎口蓋裂者を対 象に，それらの上顎歯列弓の狭窄の有無と臼歯部の咬合 状態を詳細に把握し, 咬筋の筋活動量に与える影響を調 べることを目的とした。

咬合状態を評価する指標として対咬接触歯数 ${ }^{1,10)}$ や対 咬接触点数, 対咬接触面積 ${ }^{3}{ }^{111}$, などの計測方法が用い られている。しかし，これらの方法は上下顎の咬合接触 している歯数や接触点数のみを数值化したもので, 対合 歯間の接触部位や煩舌的関係を考慮していないという久 点がある.今回考案した咬合安定指数は，咀嚼筋筋活動 に影響をおよぼす機能的な咬合状態を表す要因を十分に 含んだ評価を行うために，対咬接触歯数のみでなく，対 合歯の咬合接触部位や煩舌的位置関係を考慮に入れた指 数である.

今までの咀嚼筋の筋電図計測では, 被験筋の特定部位 から双極表面電極により筋活動電位を導出しているもの が多い.しかし, 咬筋の筋活動電位は同一被験者でも導 出部位によって差があり，さらに個体間の違いも大きい。 そのため, 電極の貼付位置の違いや, 電極の再貼付時のず れによって計測した筋活動量が大きく異なってしまう ${ }^{12-15)}$. 本研究では篠田ら ${ }^{6)}$ が開発した 9 チャンネル筋電図分析 システムを用い, 被験者の咬筋全域の筋活動電位を左右 側同時に計測することにより，個体内および個体間の電 極の貼付位置による筋活動量のバラツキを最小限にとど め，かつ同じ個体での左右側咬筋の筋活動量の比較を可 能にした。

2. 小児唇顎口蓋裂者の咬合安定性と咬筋筋活動量につ いて

矯正治療前の片側性唇顎口蓋裂者における咬合接触点 数と接触面積を調べた作田 ${ }^{3)}$ の報告では，正常咬合者に 比べ片側性唇顎口蓋裂者ではその接触点数や接触面積は 少なく, さらに狭窄歯列弓をもつ者は狭窄歯列のない者 よりも50\%以下の咬合接触点数と接触面積であったとし ている. 本研究での小児被験者の咬合安定指数の結果も, ほぼ同様な傾向を示していた。

本研究において小児狭窄群の田歯部での咬合状態を観
察した結果，狭窄側では㚘舌的に逆被蓋であったにもか かわらず，咬合接触状態は対合歯と複数点または面で接 触していたものが多く良好であった，それに対して，非 狭窄側では逆被蓋になっていないが咬頭対咬頭で咬合し ているものが多く，そのため咬合接触状態が劣る場合が 多かった。したがって, 今回用いたOSIは被蓋状態より 咬合接触状態に比重をおいた指数であるため，小児狭窄 群のOSI值は狭窄側の方が非狭窄側より高くなったもの と考えられる.

咬筋筋活動量と咬合の安定性とに関する唇顎口蓋裂者 以外の不正咬合者における研究では，不正咬合者の咬筋 筋活動量は，正常咬合や矯正治療を終了し咬合が安定し た場合に比べて低い值を示すと報告されている ${ }^{16-20)}$ 。ま

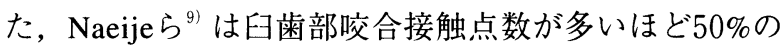
咬み締め時の咬筋筋活動量は大きかった，と報告してい る. 本研究結果での咬合安定指数と筋活動量との高い正 相関が得られたことも考えあわせると，臼歯部咬合の安 定性と咬筋筋活動量との間には強い関連性のあることが 示唆された。

乳児における筋の運動単位活動電位は成長に伴い成人 になるまで増加を示すとSaccoら ${ }^{21)}$ は報告している。さ らに, Pancherz ${ }^{22)}$ は成人正常咬合者群と小児正常咬合者 群との咬み締め時の咬筋筋活動を比較し, 成人の咬筋筋 活動が小児の約1.5倍であると報告していた。本研究で の正常群と非狭窄群の小児と成人の咬筋筋活動量を比較 すると，それぞれ約 1.4 倍，約 1.5 倍であり，同様な結果 を示していた。一方，狭窄群では成人が小児の約 3.5 倍 と著しく増加しており，これは咀嚼筋の発育や歯列の成 長変化などの加齢現象ばかりではなく, 矯正治療による 臼歯部咬合の安定性の改善も強く影響している結果と考 えられる。したがって，唇顎口蓋裂の矯正治療は審美的 な改善ばかりではなく，咀嚼咬合機能の回復という意味 でも非常に重要であることが強く示唆された。

\section{3. スプリント装着の咬筋筋活動量への影響について}

Jiménez ${ }^{23)}$ は咬合が不安定な場合には，咬合接触して いる限局した歯群に咬合力が集中することによって生じ る顎口腔系への障害を回避するため, 筋力は分散すると 述べている．本研究での小児唇顎口蓋裂者の狭窄群への スプリント装着による咬筋筋活動量の増加は，不安定な 上下顎の咬合接触状態によって筋の機能力を十分に発揮 することのできなかった咬筋が咬合を安定させることに より，潜在的な機能力を発揮したために正常者と同程度 まで回復したことによるものと考えられる. 


\section{V. 結 論}

唇顎口蓋裂による臼歯部咬合の不安定が咬筋筋活動量 に与える影響を 9 チャンネルリ電図分析システムを用い 調べた結果，以下のことがわかった。

1. 小児群では正常群と非狭窄群との咬合安定指数と咬 筋筋活動量はほぼ同じであったのに対し，狭窄群の 咬合安定指数と咬筋筋活動量は他の 2 群に比べ著し く低い值を示し，しかも左右側の非対称性も大きか った。

2. 咬合安定指数と咬筋筋活動量とには強い正の相関が 認められた。

3. 咬合安定性が最も低かった小児狭窄群にスプリント を装着させ，咬合を安定させた結果，咬筋筋活動量 は増加し，左右側の非対称性も著明に減少した。

4. 小览から成人への咬合安定指数と咬筋筋活動量の変 化を比較した結果, 非狭窄群は正常群と同程度の増 加を示したのに対し, 狭窄群は著しい増加を示し た。

\section{文献}

1 ）蔡 吉陽：片側性唇顎口蓋裂者の咀嚼時における咀 嚼筋筋電図に関する研究, 広大歯誌, 20：287-308, 1988.

2 ）泉 俊郎, 荻野 久, 水室利彦ほか：片側性唇顎口 蓋裂者の咀嚼筋活動と下顎頭の位置に関する研究, 日口蓋誌，15：178-188，1990.

3 ）作田 守：唇顎口蓋裂患者の咀嚼障害に関する研究, 歯医学誌, $5: 32-46,1986$.

4 ) 安藤葉介, 石川博之, 大熊信行ほか：片側性唇顎口 蓋裂患者における上顎歯槽部の形態と上顎骨の成長 変化について，日口蓋誌，14：296，1989.

5 ) 高道 理, 石塚一夫, 大畑 昇ほか：下顎枝矢状分 割術後 5 年以上経過観察を行った 14 症例の顎態およ び咬合状態の後戻りとその対策について II ，顎変形 誌, 4:51-52, 1985.

6 ）篠田充巨, 松野 功, 今井 徹ほか：下顎の偏位が 咬筋筋活動に及ぼす影響一多チャンネル筋電図分析 システムによる検討一, 日矯歯誌, 52：119-132, 1993.

7 ) 田部孝治：咀嚼筋活動と顎・顔面形態に関する研究, I. 咬筋活動の筋電図学的特性と閉顎力について, 日矯歯誌，35：239-254，1976.

8 ）平尾文昭：下顎の位置変化が咀嚼筋活動に及ぼす影
響に関する研究，歯科学報，77：1167-1204，1977.

9 ) Naeije, M., McCarroll, R. S. and Weijs, W. A.: Electromyographic activity of the human masticatory muscles during submaximal clenching in the inter-cuspal position, J Oral Rehabil, $16: 63-70,1989$.

10）米田尚登，蔡 吉陽，竹中美奈子ほか：片側唇顎口 蓋裂者における対咬接触歯数と顎態の関連一とくに 下顎骨の形態についてー，日矯歯誌，42:158-167, 1983.

11）栗本清勝：咀嚼能率に関与する因子の研究一咬合面 形態・咬合力との関係一, 補綴誌, $22: 166-183$, 1978.

12）松野 功, 今井 徹, 中村進治ほか：20ch筋電図分 析システムによる咬筋筋活動の研究，医用電子と生 体工学, $27: 121-126,1989$.

13) Ahlgren, J.: Mechanism of mastication, a quantitative cinematographic and electromyographic study of masticatory movements in children, with special reference to occlusion of the teeth, Acta Odontol Scand, 24 (Suppl. 44) : 1-109, 1966.

14）岡根秀明, 津島隆司，三善陸朗ほか：電極の位置と 極間抵抗が咬筋筋電図に及ぼす影響について，補緅 誌, $23 ： 164-167,1979$.

15）前田照太，藤井弘之，犬伏義臣：咀嚼筋表面筋電困 のパワースペクトルの変動要因について, 補緅誌, $24: 322-328,1980$.

16）今井香樹：反対咬合治療前後における咀嚼関連筋群 の筋電図に関する研究-F.K.O.適応者と考えられる ものについてー，日大歯学， $48 ： 720-744 ， 1975$.

17）梅澤富获：咀嚼に関与する笳の筋電図学的研究一反 対咬合治療前後の比較, 日大歯学, 50：676-697, 1976.

18) Pancherz, H.: Activity of temporal and masseter muscles in class II, division 1 malocclusions, Am J Orthod, 77 : 679-688, 1980.

19) Pancherz, H. and Anehus-Pancherz, M.: Muscle activity in class II, division 1 malocclusions treated by bite jumping with the Herbst appliance, Am J Orthod, 78 : 321-329, 1980.

20）大道貞祥：混合歯列期における正常咬合者と上顎前 突者の顎の運動学的ならびに筋電図学的研究, 岐歯 学誌, $16: 147-163,1989$.

21) Sacco, G., Buchthal, F. and Rosenfalck, P.: Motor unit potentials at different ages, Arch Neurol, 6:366-373, 1962. 
22) Pancherz, H.: Temporal and masseter muscle activity in children and adults with normal occlusion, Acta Odontol Scand, $38: 343-348,1980$.
23) Jiménez, I. D.: Dental stability and maximal masticatory muscle activity, J Oral Rehabil, $14: 591-598,1987$. 